\title{
Ability of Net Income in Predicting Dividend Yield: Operating Cash Flow as a Moderating Variable
}

\author{
Zarah Puspitaningtyas \\ Department of Business Administration, \\ University of Jember, Indonesia;
}

\begin{abstract}
The purpose of this study is to determine the ability of net income in predicting dividend yield with operating cash flow as a moderating variable on manufacturing companies of the consumer goods industry sector listed in the Indonesia Stock Exchange on the period 2012-2016. The sample is selected by using purposive sampling technique. The data analyzed by using moderated regression analysis. The result of analysis shows that, at the 0.05 level of significance, operating cash flow significantly influences the dividend yield, while net income does not affect the dividend yield. However, operating cash flow is able to moderate significantly the effect of net income on dividend yield. These results indicate that net income is unable to signal investors to predict dividend yields. However, net income will be a significant explanation of the dividend yield when operating cash flow acts as a moderating variable.
\end{abstract}

Keywords: net income, cash flow operation, dividend yield.

\section{INTRODUCTION}

Investment is an activity of placing funds in one or more assets in the hope of obtaining future returns. Purchase of shares is one of the investment activities. The expected return on investment can be either capital gains or dividends. Capital gain is the rate of return obtained from the difference between the purchase price and the selling price of the stock. Dividends are the percentage of profits earned by investors based on the proportion of share ownership of a company $[3 ; 6 ; 8 ; 11 ; 12 ; 20 ; 23 ; 27]$.

Financial market allocates investment funds to the most profitable projects by identifying information about investments characteriszed by the highest rate of return [14; 16]. For investors who behave risk aversion, will tend to choose the return on investment in the form of dividends rather than capital gains. Cause, dividend yield tends not to be influenced by market conditions so that it contains a lower level of uncertainty than capital gain.

The level of dividend yield is an indicator of increased welfare for investors. Investor's expectation on investment activity is to get the highest rate of return at certain risk level [11; $23 ; 25]$. At a certain level of risk, investors tend to choose investments that generate the highest returns. Meanwhile, at a certain rate of return, investors tend to choose the investment with the lowest risk level. Therefore, investors are concerned to predict level of the expected dividend yield in the future. However, the level of dividend yield is not easy to predict. Many factors influence the company's dividend policy, some of which are net income and operating cash flow. The purpose of this study is to determine the effect of net income to dividend yield with operating cash flow as a moderating variable on manufacturing companies of consumer goods industry sector listed in Indonesia Stock Exchange on period 2012 - 2016.

The level of profit distributed to investors depends on the company's dividend policy. Company policy relating to dividend payout is to determine whether the profit earned by the 
company in any period will be paid in whole or in part to its investors as dividend yield [4; 20; 34]. Investors are always expecting high dividend yields, but companies have strategic considerations regarding sustainability and future growth of the company.

Kodrat and Herdinata [15] state that each "rupiah" of dividend payments will reduce the retained earnings that should be reinvested by the company through the purchase of new assets. The lost share of retained earnings shall be replaced by issuing and selling new shares. Based on these considerations, not all profits earned by the company will be paid as dividend yield to investors. There is a portion of the profits the company will reinvest as part of retained earnings.

The greater the proportion of the profits paid to investors as a dividend yield, the less the residual profits to be reinvested in the firm as part of retained earnings [31]. As a result, it will minimize the company's ability to increase future growth. The growth of companies that tend to decline, will eventually reduce the growth of dividends in the future.

Based on this description, the problem formulation in this study is as follows: 1) does net income affects dividend yield?, 2) does operating cash flow affects dividend yield?, and 3) does operating cash flow moderates the effect of net income on dividend yield? Several previous studies have conducted studies that analyze the ability of net income and operating cash flow in predicting dividend yield, but show inconsistencies in the results, thus becoming an interest to conduct this study.

\section{LITERATURE REVIEW}

\section{The Signaling Theory and Predictive Value of Accounting Information}

Signaling Theory suggests that stock prices will likely increase if there is an announcement of dividend increases, and vice versa. Based on this theory, it is not an increase or decrease in dividend that causes an increase or decrease in stock prices, but the prospects of the company contained in the announcement information. Because, according to this theory, dividend announcement has information content [8]. High performing companies will pay higher dividend yields.

Signaling theory describes an action taken by company management to provide a signal or a hint for investors about how the prospects of the company in the future [3; 34]. This signal is in the form of accounting information contained in the company's financial statements in a period. The information is expected to be useful for investors to make investment decisions. The company's management objective of publishing its financial statements is to signal investors to future prospects.

Profit is one of the accounting information contained in the financial statements. The financial statements are records of accounting information sourced from a company's financial transactions that are useful to describe the performance of the company in a period [24; 26 ; 30]. In order to be usefulness to the users for investment decision making, the accounting information presented in the financial statements should contain predictive value.

Predictive value is defined as the usefulness of accounting information for investment decision making by evaluating past, present, and future events [24; $27 ; 38]$. The historical information presented in the financial statements is useful to predict the company's ability to improve the welfare of its investors, one of which is proxied in increasing dividend yield. Thus, the predictive value of the accounting information contained in the financial statements is useful for assessing the performance of a firm over a period. The predictive value contained in the 
accounting information is expected to provide a signal for market participants to predict the sustainability and future growth of a company.

\section{Theory of The Dividend Policy}

The dividend policy includes a decision on whether the profits earned by the company over a period will be distributed to investors as dividend yield or to be reinvested as part of retained earnings $[2 ; 3 ; 7 ; 10 ; 20 ; 31 ; 34 ; 36]$. The dividend distribution will give a positive signal about the company's performance in a period to investors. In general, the payment or distribution of dividends is made in cash.

Wiagustini [2010] mentioned that there are several factors that influence dividend policy, including: 1) cash position reflecting the company's liquidity. When a company is able to obtain sufficient net income, but management takes a policy to reinvest profits earned into real assets, then the company can't make a dividend in cash; 2) the need to make payments on the obligations of the company; 3 ) policies related to high levels of expansion that require substantial funds. Therefore, the profit earned is better retained; 4) company access in the capital market; and 5) shareholder positions in the tax group.

There are several theories underlying dividend policy, such as: Irrelevant Dividend, Bird-inthe-Hand Theory, and Tax Differential Theory. The Irrelevant Dividend Theory proposed by Miller and Modigliani (hereinafter referred to as MM Theory), argues that dividend payout has no effect on shareholder prosperity. Under these conditions, the value of the firm is determined by the earning power of the firm's assets. Thus, the value of the firm is determined by the investment decision. Bird-in-the Hand Theory proposed by Gordon and Lintner, argues that the increase in the company's equity cost is due to a decrease in dividend payouts, as investors are more confident of dividend payouts than the capital gains generated. This theory assumes that investors see a bird in hand is more valuable than a thousand birds in the air. Capital gain is seen as riskier than a more certain dividend yield. Therefore, investors will demand a higher profit rate for each dividend yield reduction. Tax Differential Theory proposed by Lizenberger and Ramaswamy, argues that in relation to the personal income tax, the relevant income for the investor is income after tax, so that the required profit is also after tax. In relation to this theory, investors prefer to receive a higher capital gain compared to high dividends. Investors tend to prefer companies to hold profit after tax and are used for investment financing rather than making dividend payments in cash $[1 ; 8 ; 13 ; 15 ; 18 ; 22 ; 36]$.

\section{The Dividend Yield}

Dividend yield is a dividend policy reflected in the dividend payout ratio. The dividend payout ratio is a share of the profits earned by the company and distributed to investors in the form of dividends for each common shareholding. Dividend payout ratio in period $t$ is measured through dividend per share ratio in period $t$ and earning per share in period $t$. Dividend per share reflects a measure of the amount of income distributed to investors in the form of dividends for each shareholding sheet. Dividend per share in period $t$ is measured by dividend paid ratio in period $t$ and number of shares outstanding in period $t$. Earnings per share represents a measure of the amount of income available to investors for each shareholding sheet. Earnings per share in period $t$ is measured by comparison of earning after taxes in period $t$ and number of shares outstanding in period $t[5 ; 6 ; 21 ; 25 ; 27 ; 32]$.

This study uses dividend payout ratio as indicator of dividend yield. The higher dividend payout ratio is predicted to increase profits for investors. On the other hand, also assessed will weaken the internal financial, because it will reduce the retained earnings, and vice versa. 
Therefore, in making dividend policy, it should consider the factors that will assist management in determining the share of the profits to be paid to investors as dividend yield.

\section{Net Income and the Dividend Yield}

The share of the profit that can be distributed to investors as dividend income is part of the company's profits after deducting its fixed expenses (such as interest expense, tax expense). The share of profit is referred to as earnings after taxes or net income $[27 ; 36]$. The amount of funds that can be distributed as dividends or reinvested as retained earnings equal to the amount of net income obtained by the company in a period.

Profit is information contained in the income statement. Profit is seen as the best indicator of company performance achievement in a period. That is, high or low performance of the company is reflected in the large or small profits that can be obtained by the company in a period. Without profits it will be difficult for the company to maintain its sustainability. For investors, profits that can be obtained by the company is also very important, because investors are always expecting a rate of return from investment activities $[29 ; 30 ; 32 ; 35 ; 38]$.

The level of net income is predicted to affect the dividend yield. That, the greater the profits earned by the company, the greater the dividend yield expected by investors in the future. The higher net income, the company is considered capable of achieving high dividend yield, and vice versa. Theoretically, companies that have the ability to earn high net income, are considered to make large dividend payouts. However, companies that have the ability to earn high net income may not necessarily pay large amounts of cash dividends, as the company may plan to use part of the net profit earned as retained earnings [20;21].

Investors who engage in investment activities in the company's common stock expect to obtain dividend yield in the future. This raises the question, whether the high factor or low net income earned by the company can affect the dividend yield for investors? This study predicts that net income affects dividend yield. This prediction refers to the results of several previous studies $[9 ; 28 ; 33 ; 37]$ which have proved that net income has a significant effect on dividend yields proxied by dividend payout ratio. However, it does not refer to the results of a study by Noviyanto [21] which proves that net income has no effect on dividend yield.

\section{Operating Cash Flow and the Dividend Yield}

The policy of dividend distribution must be one of consideration of the availability of cash, because even if the company is profitable, but if the amount of available cash is insufficient to be paid cash dividend then the company is likely to take the decision to hold the profit to be reinvested. Therefore, the policy of dividend payout can't be determined only with the consideration of the acquisition of net income, but it is also important to consider the operating cash flow.

There are three activities in the cash flow statement $[30 ; 32 ; 36]$, ie operating activities, investment activities, and financing activities. Of the three activities, which tend to be associated with dividend policy making is cash flow originating from operating activities. Therefore, operating cash flow is an indicator that reflects the ability of the company to pay its obligations, the ability to maintain its operations, the ability to pay cash dividends, and the ability to make new investments without relying on external funding sources.

Operating cash flow is one of the cash flow information that is the focus for the users of financial statements. This is because the operating cash flow is the main indicator to determine whether a company's operating activities are capable of generating sufficient cash flow to 
finance the company's operations, repay loans, and distribute dividends without using external funding sources [38]. In addition, to maintain the sustainability of its business over the long term, a company must be able to generate positive net cash flow from operating activities. The positive net cash flows reflect the company having sufficient financing. Conversely, companies with negative net cash flows indicate that the company does not have the ability to raise cash from other sources over a relatively long period of time.

Operating cash flow is a cash flow from operating activities derived from the main income generating activities of a company. Generally, it comes from transactions that affect the determination of net profit (or loss) earned by a company for a period. The cash position reflects the availability of cash from a company. The availability of cash becomes an important factor in determining the amount of dividends to be paid to investors. Cash dividend is the cash outflow for the company. Therefore, if the company takes a policy to pay cash dividends to its investors, then there should be sufficient cash to make the payment. For companies that have a relatively small cash availability, the dividend payout ratio tends to be small, and vice versa $[21 ; 31]$.

This study predicts that operating cash flow affects dividend policy. These predictions refer to the results of several previous studies $[9 ; 18 ; 21 ; 28 ; 37]$ which have proved that operating cash flow significantly affects dividend policy. However, it does not refer to the results of a study by Masrifah [19] which proves that operating cash flow has no effect on dividend yield.

\section{The Conceptual Framework and Hypothesis}

The conceptual framework is presented in Figure 1 below.

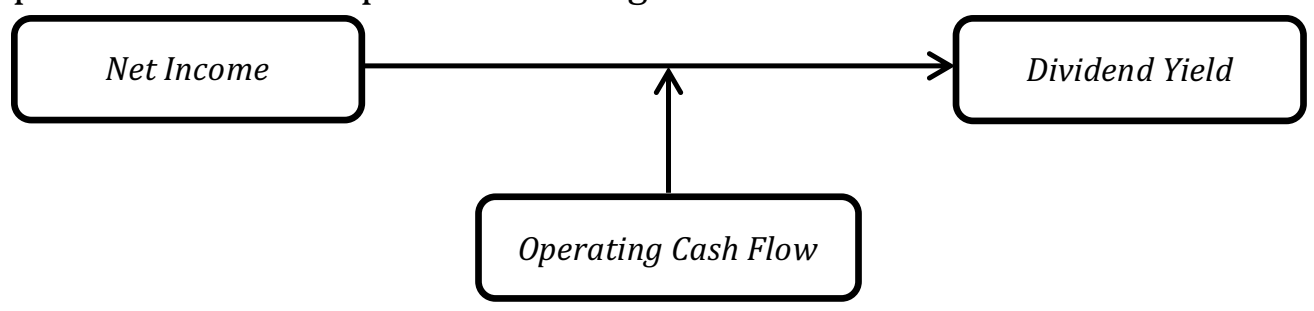

Figure1: The Conceptual Framework

Based on the conceptual framework, the following hypothesis are formulated:

$\mathbf{H}_{\mathbf{1}}$ : net income affects the dividend yield.

$\mathbf{H}_{2}$ : operating cash flow affects the dividend yield

$\mathbf{H}_{3}$ : operating cash flow moderates the net income effect on dividend yield

\section{Population and Sample}

\section{METHODOLOGY}

The population in this study is a manufacturing company in the consumer goods industry sector listed in the Indonesia Stock Exchange on the period 2012 - 2016, which amounted to 37 companies. Furthermore, the selected sample based on purposive sampling technique with the following criteria:

a. Companies included in the population and publish summary of financial statements during the period 2012 - 2016;

b. Companies selected based on criteria (a) once distributed cash dividends for the period 2012 - 2016; and

c. Companies selected based on (a) and (b) have a positive net income in the financial statements published during the period 2012 - 2016. 
Based on the sample selection criteria, then determined the number of samples of 29 companies. Furthermore, the number of observations is determined based on the pooling technique, ie the number of samples multiplied by the number of years of observation, then obtained the amount of data observed as much as 145 observations.

\section{Sources of the Data}

The data used in this study is secondary data, sourced from a summary of financial statements published on the Indonesia Stock Exchange website (www.idx.co.id).

\section{Variable Operational Definition}

There are two categories of variables in this study: 1) dividend yield as dependent variable (Y), 2) net income as independent variable $\left(\mathrm{X}_{1}\right)$, and 3 ) operating cash flow as moderating variable $\left(\mathrm{X}_{2}\right)$.

a. Dividend yield (Y), measured by dividend payout ratio, is ratio of dividend per share and earnings per share.

b. Net income $\left(\mathrm{X}_{1}\right)$ shows the amount of excess earnings after deducting the total expenses incurred in the income statement for a period.

c. Operating cash flow $\left(\mathrm{X}_{2}\right)$ shows the sum of all cash receipts transactions related to sales revenue and cash disbursements related to overall operating costs.

\section{Technique of Data Analysis}

The data collected, then analyzed using moderated regression analysis. However, previously performed a classical assumption test to obtain the best regression analysis, linear, unbiased, and estimated (BLUE). The classical assumption test consists of: normality test, autocorrelation test, and heteroscedasticity test. In this case the classical assumption of multicollinearity test is not done, because in the formula of regression equation with moderating variables there are multiplication $\mathrm{X}_{1}$ (as independent variables) and $\mathrm{X}_{2}$ (as moderating variables) so that there is possible correlation between the two variables. The result of the classic assumption test shows that the analyzed data has fulfilled the three classical assumptions, so it can be continued to moderated regression analysis with equation formula as follows:

Dividend Yield $=\mathrm{a}+\mathrm{b} 1$ Net Income $+\mathrm{b} 2$ Operating Cash Flow + b3 Net Income* Operating Cash Flow + e

$\mathrm{DY}=\mathrm{a}+\mathrm{b} 1 \mathrm{NI}+\mathrm{b} 2 \mathrm{OCF}+\mathrm{b} 3 \mathrm{NI}^{*} \mathrm{OCF}+\mathrm{e}$

\section{RESULTS AND DISCUSSION}

The results of moderated regression analysis are presented in Table 1.

Table 1. The results of moderated regression analysis.

\begin{tabular}{|c|c|c|c|}
\hline Model & Regression Coefficient & Significance & Conclusion \\
\hline Constants & 1.767 & 0.005 & \\
NI & 0.015 & 0.463 & Not significant \\
OCF & 0.471 & 0.012 & Significant \\
NI_OCF & 0.423 & 0.027 & Significant \\
\hline R & 0.601 & & \\
R square & 0.512 & & \\
Adjusted R square & 0.506 & & \\
F value & 128.305 & & \\
Sig. F & 0.000 &
\end{tabular}

Source: the results of analysis (2017)

Based on Table 1 we can get the regression equation with the moderating variable as follows: 
$\mathrm{DY}=1,767+0,015 \mathrm{NI}+0,4710 \mathrm{CF}+0,423 \mathrm{NI}$-OCF + e. Furthermore, at the $5 \%$ significance level, the results of the analysis show that:

a. Net income did not affect the dividend yield with significance value of $0.463(0.463>$ 0.05). That is, the hypothesis that net income affects dividend yield is unacceptable $\left(\mathrm{H}_{1}\right.$ is rejected).

b. Operating cash flow has significant effect on dividend yield with significance value $0.012(0.012<0.05)$. That is, the hypothesis that stated operating cash flow effect on dividend yield is acceptable $\left(\mathrm{H}_{2}\right.$ accepted). Regression coefficient shows positive sign, meaning that operating cash flow have positive effect to dividend yield. The higher the operating cash flow reflects the higher the dividend yield, and vice versa.

c. Operating cash flow is able to moderate significantly the effect of net income on dividend yield with a significance value of $0.027(0.027<0.05)$. That is, that the hypothesis that the operating cash flow moderate the effect of net income on dividend yield is acceptable $\left(\mathrm{H}_{3}\right.$ accepted). The regression coefficient shows a positive sign, this indicates that the effect of moderation given is positive. This means that the higher the operating cash flow, the higher the effect of net income on the dividend yield.

The test results show that operating cash flow significantly acts as an independent variable and moderating variable. Therefore, it can be concluded that operating cash flow is a quasi moderator, that is, variables that moderate the effect of net income on dividend yield as well as become independent variables affecting dividend yield.

The adjusted $\mathrm{R}$ square value in the regression model with the moderating variable is 0.506 or $50.6 \%$. This means that the regression model with operating cash flow as the moderating variable is able to explain the variation of dividend yield variable is $50.6 \%$, while the remaining $49.4 \%$ is explained by other factors (e) outside the model and not observed.

$\mathrm{F}$ test results show the value of $\mathrm{F}$ of 128.305 with a significance value of $0.000(0.000<0.05)$. Thus, it can be concluded that net income and operating cash flow as independent variables and operating cash flow as a moderating variable simultaneously affect the dividend yield. In other words, regression models with moderating variables can be significantly used to predict dividend yields through net income and operating cash flows as independent variables and operating cash flow as moderating variables.

The results of this study indicate that companies that have the ability to obtain a positive net income, do not always reflect the amount of cash availability sufficient to make cash dividend payments. This is because, the income earned by the company as a net income indicator is not always in the form of cash, but there is a form of receivables. Sometimes when the net income earned by the company decreases, but because it has sufficient cash availability, the company may consider making cash dividend payments to its investors as a dividend yield. The amount of cash flows generated from operating activities is an indicator that determines whether the company's operating activities can generate sufficient positive cash flows to conduct the company's operating activities, repay loans, pay dividends, and make new investments without relying on external sources of funding.

The level of the ability of a company to earn a profit in a period will determine the choice of company dividend policy. Profit earned will be distributed as dividend yield to investors or will use it to be reinvested as part of retained earnings. In the event that a company is in a nonprofitable condition, the tendency of profit to be obtained will be more widely used to improve the position of its capital structure. In addition, the amount of cash flow sourced from the 
company's operations becomes an indicator that determines the ability of the company to obtain sufficient cash to distribute dividends to its investors.

Based on these results, it can be concluded that the value of net income that can be obtained by the company in a period is not the main thing used in considering the payment of cash dividend, but management must also consider the operating cash flow reflecting the cash availability in a period. Therefore, the company uses cash in making cash dividends, so the company must have sufficient cash availability to make the payment. When the available cash is insufficient for cash dividend payments, it is possible for the company to make a decision to withhold the profit to be reinvested instead of being paid to its investors as a dividend yield. These results support Pourheydari's [22] statement which suggests that the determinant of dividend payout is a stable cash flow. Thus, accountants as accounting information providers, should make operating cash flow as one of the important information for investors, containing predictive value and able to signal investors to predict future prospects, including predicting the company's ability to do so future cash dividend payout to investors as dividend yield.

\section{CONCLUSION}

The results of this study prove that operating cash flow has a significant effect on dividend yield, while net income does not affect the dividend yield. However, when operating cash flow acts as a moderator it can strengthen the net income effect on dividend yield. That is, operating cash flow is able to moderate significantly the effect of net income on dividend yield. These results indicate that net income is unable to signal investors to predict dividend yields. However, net income will be a significant explanation of the dividend yield when operating cash flow acts as a moderating variable.

\section{References}

Al-Ajmi, J., and Hussain, H.A, Corporate Dividends Decisions: Evidence from Saudi Arabia, The Journal of Risk Finance, 2011, 12(1): p. 41-56.

Al-Twaijry, A.A., Dividend Policy and Payout Ratio: Evidence From the Kuala Lumpur Stock Exchange, The Journal of Risk Finance, 2007, 8(4): p. 349-363.

Alamsyah, S., Pengaruh Profitabilitas terhadap Nilai Perusahaan, Relevansi Nilai Informasi Akuntansi, Keputusan Investasi, Kebijakan Dividen sebagai Variabel Intervening, Competitive, 2017, 1(1): p. 136-161.

Ali, A., Fengju, X., Goncalves, A., and Saeed, U., Determinants of Dividend Policy: Evidence from Textile Industry of Pakistan., International Journal of Arts \& Sciences, 2015, 8(8): p. 45-52.

Ariyanti, P.S., Insider Ownership, Dividen, dan Kebijakan Hutang: Peran Moderasi Free Cash Flow, JRAK, 2013, 9(1): p. 69-91.

Bodie, Z., Kane, A., and Marcus, AJ., Investment, 8th edition, 2009, McGraw-Hill Companies, Inc.

Brigham, E.F., Houston, J.F., Dasar-Dasar Manajemen Keuangan, 2010, Jakarta: Salemba Empat.

Bushra, A., and Mirza, N., The Determinants of Corporate Dividend Policy in Pakistan, The Lahore Journal of Economics, 2015, 20(2): p. 77-98.

Christi, I., and Wijayanti, I., Faktor-faktor yang Memengaruhi Kebijakan Dividen: Studi Kasus pada Bank-bank yang terdaftar di Bursa Efek Indonesia, Jurnal Akuntansi \& Bisnis Perbanas Institute, 2013, 1(1): p. 16.

Halim, A., Manajemen Keuangan Bisnis, 2007, Bogor: Ghalia.

Hartono, J., Teori Portofolio dan Analisis Investasi, 2008, Yogyakarta: BPFE.

Hidayat, T., Buku Pintar Investasi, 2010, Jakarta: Mediakita.

Impson, C.M., and Karafiath, I., A Note on the Stock Market Reaction to Dividend Announcements, The Financial Review, 1992, 27(2): p. 259-271.

Jain, P., and Chu, Q.C., Dividend Clienteles: a Global Investigation, Rev Quant Finan Acc, 2013, 42, p. $509-534$.

Kodrat, D.S., and Herdinata, C., Manajemen Keuangan based on Empirical Research, 2009, Yogyakarta: Graha Ilmu. 
Lazarov, D., Miteva-Kacarski, E., and Nikoloski, K., An Empirical Analysis of Stock Market Development and Ecocomic Growth: the Case of Macedonia, South East European Journal of Ecocomics and Business, 2016, 11(2): p. 71-81.

Manurung, I.A., Pengaruh Laba Bersih dan Arus Kas Operasi terhadap Kebijakan Dividen pada Perusahaan manufaktur yang Go Public, Jurnal Akuntansi, 2007, p. 1-5.

Manurung, I.A., Siregar, H.S., Pengaruh Laba Bersih dan Arus Kas operasi terhadap Kebijakan Dividen, Jurnal Akuntansi, 2009, p. 3.

Masrifah, I., Analisis Hubungan Laba Bersih, Arus Kas Operasi dan RUPS dengan Dividen Tunai pada Industri Manufaktur, Jurnal Organisasi dan Manajemen, 2014, 10(2): p. 113-123.

Mustofia, M., Puspitaningtyas, Z., and Sisbintari, I., Pengaruh Profitabilitas dan Investment Opportunity Set terhadap Kebijakan Dividen, Jurnal Akuntansi Aktual, 2014, 2(4): p. 219-228.

Noviyanto, A., Pengaruh Laba Bersih, Arus Kas Operasi, dan Likuiditas terhadap Kebijakan Dividen, Jurnal Profita, 2016, 8: p. 1-13.

Pourheydari, O., A survey of Management Views on Dividend Policy in Iranian Firms, International Journal of Islamic and Middle Eastern Finance and Management, 2009, 2(1): p. 20-31.

Puspitaningtyas, Z., Pengaruh Rasio Likuiditas dan Financial Leverage terhadap Pengembalian Investasi berupa Dividend Yield, Jurnal Ekonomi \& Bisnis (JEB), 2012a, 6(1): p. 41-46.

Relevansi Nilai Informasi Akuntansi dan Manfaatnya Bagi Investor, Ekuitas: Jurnal Ekonomi dan Keuangan, 2012b, 16(2): p. 164-183.

Prediksi Risiko Investasi Saham: Decision Usefulness Approach, 2015, Yogyakarta: Griya Pandiva.

Estimating Systematic Risk for the Best Investment Decisions on Manufacturing Comapny in Indonesia, International Management and Financial Innovations, 2017, 14(1): p. 46-54.

Puspitaningtyas, Z., and Kurniawan, A.W., Prediksi tingkat Pengembalian Investasi berupa Dividend Yield berdasarkan Analisis Financial Ratio, Majalah EKONOMI: Telaah Manajemen, Akuntansi, dan Bisnis, 2012, 16(1): p. 89-98.

Ramli, M.R, and Arfan, M., Pengaruh Laba, Arus Kas Operasi, Arus Kas Bebas, dan Pembayaran Dividen Kas Sebelumnya terhadap Dividen Kas yang Diterima oleh Pemegang Saham: Studi pada Perusahaan Manufaktur yang terdaftar di Bursa Efek Indonesia, Jurnal Telaah dan Riset Akuntansi, 2011, 4(2): p. 126-138.

Stice, E.K., and Stice, J.D., Skousen, K.F., Intermediate Accounting, 19th Edition, 2009, Cincinati, Ohio: SouthWestern Publishing, Co.

Suprapto, Informasi Laba dalam Memprediksi Arus Kas di Masa Mendatang (Studi Kasus pada Perusahaan Manufaktur di Bursa Efek Indonesia), Jurnal Ilmu Ekonomi dan Sosial, 2013, 2(2): p. 163-176.

Sutrisno, Manajemen Keuangan: Teori, Konsep, dan Aplikasi, 2009, Yogyakarta: Ekonisia.

Syamsuddin, L, Manajemen Keuangan Perusahaan (Konsep Aplikasi dalam Perencanaan, Pengawasan, dan Pengambilan Keputusan), 2007, Jakarta: PT. RajaGrafindo Persada.

Tirana, N., and Handayani, S, Pengaruh Arus Kas Operasi, laba Bersih, dan Hutang terhadap Kebijakan Dividen (Dividend Payout Ratio) pada Perusahaan Manufaktur yang Go Public di Bursa Efek Indonesia tahun 2005-2009, Jurnal Bisnis dan Manajemen, 2011, 4(1): p. 1-11.

Wardani, R.A.K., Pengaruh Aliran Kas Bebas terhadap Nilai Pemegang Saham dengan Set Kesempatan Investasi dan Dividen sebagai Variabel Moderator, Jurnal Ekonomi \& Bisnis (JEB), 2012, 6(1): p. 63-81.

Weston, JF., and Copeland, TE., Manajemen Keuangan, Edisi Revisi, Jilid 1, 2010, Binarupa Aksara Publisher. Wiagustini, N.L.P, Dasar-Dasar Manajemen Keuangan, 2010, Denpasar: Udayana University Press.

Wenas, D.D., Manossoh, H., and Tirayoh, V.Z., Analisis Pengaruh Arus Kas Operasi dan Laba Bersih terhadap Dividen Kas pada Perusahaan Properti yang terdaftar di Bursa Efek Indonesia, Jurnal EMBA, 2017, 5(1): 96-104.

Yuwana, V., and Christiawan, Y.J., Analisis Kemampuan Laba dan Arus Kas Operasi dalam Memprediksi Arus Kas Operasi Masa Depan, Business Accounting Review, 2014, 2(1): p. 1-10. 